\title{
Plant Diversity and Composition of Three Different Altitudes in Sikka Forest Area-East Nusa Tenggara
}

\author{
Abban Putri Fiqa*, Gebby Agnessya Esa Oktavia \\ Purwodadi Botanic Garden-Research Center for Plant Conservation and Botanic Garden-Indonesian Institute of Sciences, Indonesia \\ *Email: abbanpf@gmail.com \\ Submitted: 25 February 2020. Revised: 10 June 2020. Accepted: 1 July 2020
}

\begin{abstract}
East Nusa Tenggara located in the Wallacea area that has many endemic species. However, the existence of germplasm diversity in this area has been threatened due to landscape changes and deforestation. The research was conducted to identify floristic composition in Sikka forest area. This research also aimed to compare that plant composition in Sikka forest area on each of the different altitudes, including their diversity richness and environmental factors. Two sampling methods were used, which are Point-Centered Quarter (PCQ) method that applied for trees and nested sampling method $5 \times 5 \mathrm{~m}^{2}$ for sapling and $2 \times 2 \mathrm{~m}^{2}$ for ground cover. Measured parameters were Relative Density (RD), Relative Frequency (RF), Relative Coverage/dominance (RC), Important Value Index (IVI), Diversity Index $\left(\mathrm{H}^{\prime}\right)$, and Jaccard Similarity Index (J'). Research results showed that the diversity index of each region was relatively low. Plant composition of tree, sapling, and groundcover in three different altitudes was quite different. This result indicates that the plant composition in the Sikka, East Nusa Tenggara is very diverse. The temperature and relative humidity in each altitude area observed was significantly different. One of the endemic species of Flores Island, Eucalyptus urophylla, was only found at 500-700 m asl. There are very limited research on the vegetation diversity held in Flores, East Nusa Tenggara. This research can be the basic for further research in order to explore the potential diversity of flora in this area.
\end{abstract}

Key words: East Nusa Tenggara; Plant Composition; Plant Diversity; Sikka Forest

How to Cite: Fiqa, A. P., \& Oktavia, G. A. E. (2020). Plant Diversity and Composition of Three Different Altitudes in Sikka Forest Area - East Nusa Tenggara. Biosaintifika: Journal of Biology \& Biology Education, 12 (2), 192-202

DOI: http://dx.doi.org/10.15294/biosaintifika.v12i2.23565

\section{INTRODUCTION}

Indonesia forests area are among the world five highest terrestrial biodiversity. Most of them are endemic and not found elsewhere (Ministry of Environmental and Forestry of Indonesia, 2014). In fact, two areas in Indonesia (Sundaland and Wallacea) are also included in 25 biodiversity hotspots of the world. The Wallacea region is a transition zone consists of thousand islands with unique and endemic species of plants and animals that are only found in the region (Bacon et al., 2013). As one of the regions located at the Wallacea, East Nusa Tenggara together with Moluccas and Sulawesi has unique biodiversity richness especially in floristic composition (Monk et al., 1997).

The existence of germplasm diversity in this Wallacea area has been threatened by a variety of destrucive agents. The toughest deforestation that has been occurred was land conversion and natural forest fires. East Nusa Tenggara has a large savanna vegetation which is the most fire-prone vegetation in the dry season (Lipsett-Moore et al., 2018). However, the forest fires do not only occur unintentionally since indigenous people also use fires to manage their traditional agricultural system. The problem that often occurs from this burning pattern is uncontrolled conflagrations (Hirschberger, 2017). This condition also caused East Nusa Tenggara to experience a rapid loss of their forest and diversity richness because the burning process will cause various kinds of environmental problems that follow such as alien species invasion, soil damage and erosion (Juárez-Orozco et al., 2017).

Sikka Regency is an area in the eastern part of Flores Island, East Nusa Tenggara. This area is relatively fertile in East Nusa Tenggara due to the existence of Mt. Egon Ilimedo, a volcano which is still active to date. Egon Village, Waegette District, Sikka Regency attracts researcher's attention because it has a high diversity of flora and ecosystem types with a lot of potentials such as the raw material for traditional medicines (Darmayanti \& Wuryanti, 2010; Lanur \& Mago, 2018). Sikka Regency, especially Waigette District is also known as an agricultural center (Ariyanti, 2010; Ariyanti \& Mudiana, 2011).

The Egon Ilimedo Protected Forest has an area of 19,456.8 hectares. The protected forest area is determined and authorized by the Minister of Forestry with Decree (SK) number 423 / KPTS-II / 1999 concerning the map of forest area designation for the East Nusa Tenggara Province. This protected forest area covers several sub-districts in Sikka, which are Waigete, Mapitara, Doreng, Talibura, and Waiblama (Indonesian Ministry of Forestry, 1999). As in the other forest areas in East Nusa Tenggara, the Egon Ilimedo Protected Forest also experiences repeated fires every 
year, even at 2019 the wild fires have burned about 20 hectares (Amalo, 2019).

Purwodadi Botanic Garden, as one of the institutions which concerns about the plant ex-situ conservation has a big responsibility to conserve nature, including the plant species. The exploration activity is important to conduct due to the pace of rescue and preventive measures of biodiversity that is still slower than the rate of habitat destruction and loss of biodiversity in Flores Island. The research was conducted to identify floristic composition in Sikka forest area and compare their diversity richness and environmental factors on each different altitude. This research might be a basis to the next bioprospecting flora research, in Flores especially, in order to use and conserve it at the same time.

\section{METHODS}

\section{Study Area}

This study was conducted in the Egon Ilimedo Protected Forest - Sikka regency. Sikka regency is one of the regencies in the East Nusa Tenggara province, which is located on Flores Island $\left(80^{\circ} 22\right.$ to $8^{\circ} 50$ $\mathrm{S}$ dan $121^{\circ} 55^{\prime} 40^{\prime \prime}$ to $\left.122^{\circ} 41^{\prime} 30^{\prime \prime} \mathrm{E}\right)$. Before 2000 , Sikka consists of 8 districts, which is along with the implementation of regional autonomy laws, but nowadays districts were splitting become 11 districts. The total land area of the district is $1731.91 \mathrm{~km}^{2}$ (BPS Nusa Tenggara Timur, 2019. The moisture level average is about $79.3 \%$, and the temperature average is approximately $27.7^{\circ} \mathrm{C}$, while the highest rainfall usually occurs in October to March (BPS Nusa Tenggara Timur, 2019).

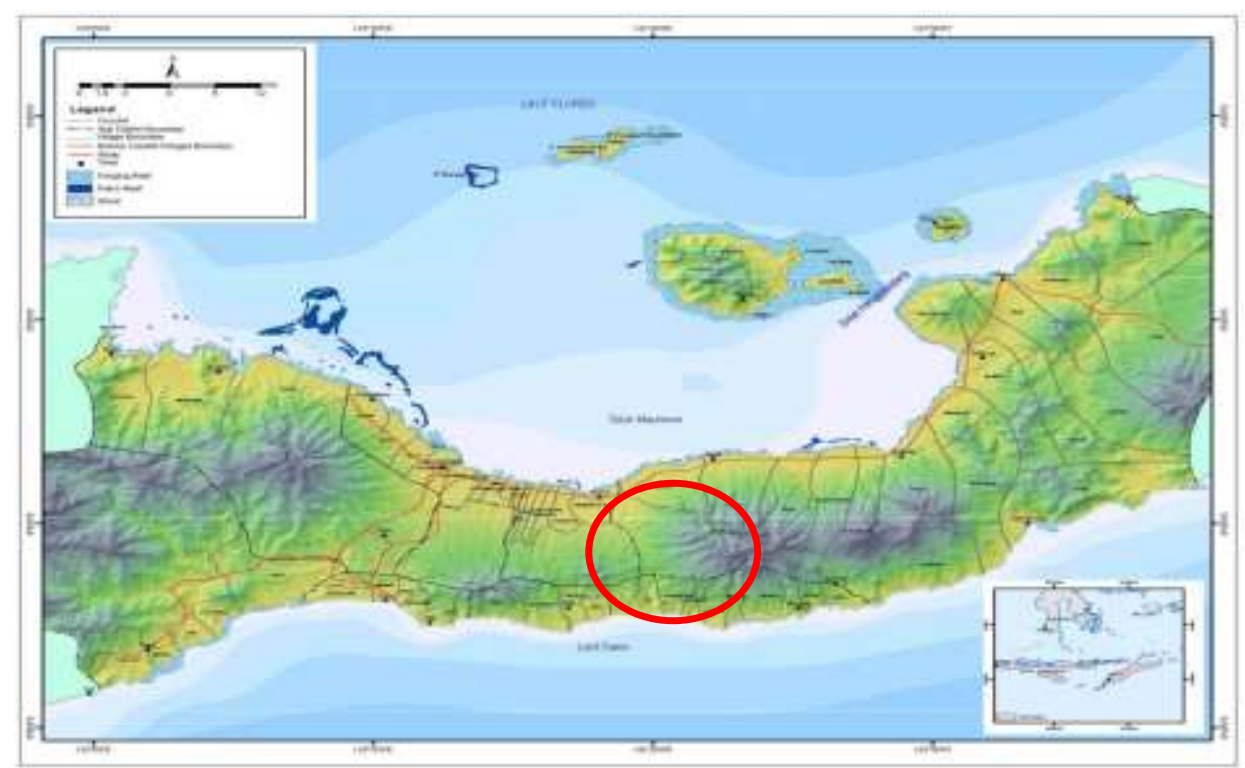

Figure 1. Area of study, Sikka Regency, Waigette District (Egon Ilimedo Protection Forest)

\section{Vegetation Sampling and Analysis}

Vegetation sampling was done by Point-Centered Quarter (PCQ) technique (quadrant method) applied for trees with diameter in breast high (dbh) of more than $30 \mathrm{~cm}$, and $5 \times 5$ and $2 \times 2 \mathrm{~m}$ plots for sapling and ground cover respectively. There were 93 sampling units taken in this study. All plant species were noted in spreadsheets to calculate their relative density (RD) and relative frequency $(\mathrm{RF})$. Only for trees, diameter, and height were also recorded to find their relative coverage/dominance (RC). Those three parameters were calculated by using the formulas (Fiqa et al., 2020) as follow:

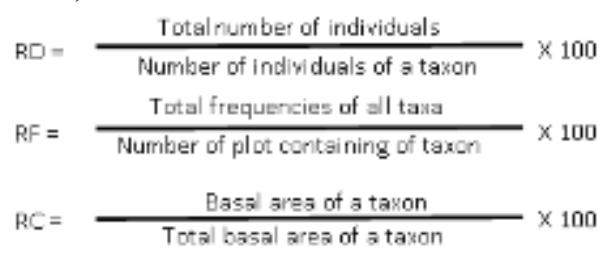

Important Value Index (IVI) was determined by adding the value of those three parameters to find the most affected species in each habitat. In addition, Shannon-Wiener diversity index (H') was counted by using this formula (Magurran, 1988):

$\mathrm{H}^{\prime}=-\Sigma$ pi $\ln \mathrm{pi} ; \mathrm{pi}=\mathrm{ni} / \mathrm{N}$,

The similarity of each observed area was described based on the Jaccard Similarity Index (Magurran, 1988) :

Jaccard Similarity Index $=\frac{\mathrm{J}}{\mathrm{a}+\mathrm{b}-\mathrm{J}} \quad \mathrm{x} 100 \%$

$\mathrm{J}$ : number of species found in both two area

$\mathrm{a}$ : number of species found in area $\mathrm{A}$

$b$ : number of species found in area $B$ 
Besides observing the composition of the vegetation structure, the differences in the three study areas were also seen from differences in environmental factors, i.e. temperature $\left({ }^{\circ} \mathrm{C}\right)$, humidity $(\%)$, and soil $\mathrm{pH}$. Ecological factors measured during the field study were then tested statistically using ANOVA.

\section{RESULTS AND DISCUSSION}

A total of 184 species representing 61 families were found in the study area, the north coast in
Waigette district. Fabaceae, Malvaceae, and Sapindaceae were the most dominant families found (Figure 2). The dominance of Fabaceae, especially Albizia spp in all observed altitude zones, indicated that the Sikka forest was already opened up. Albizia spp. is a fast-growing, cosmopolitan, and favors open with light-rich environment (Niemiec et al., 2018).

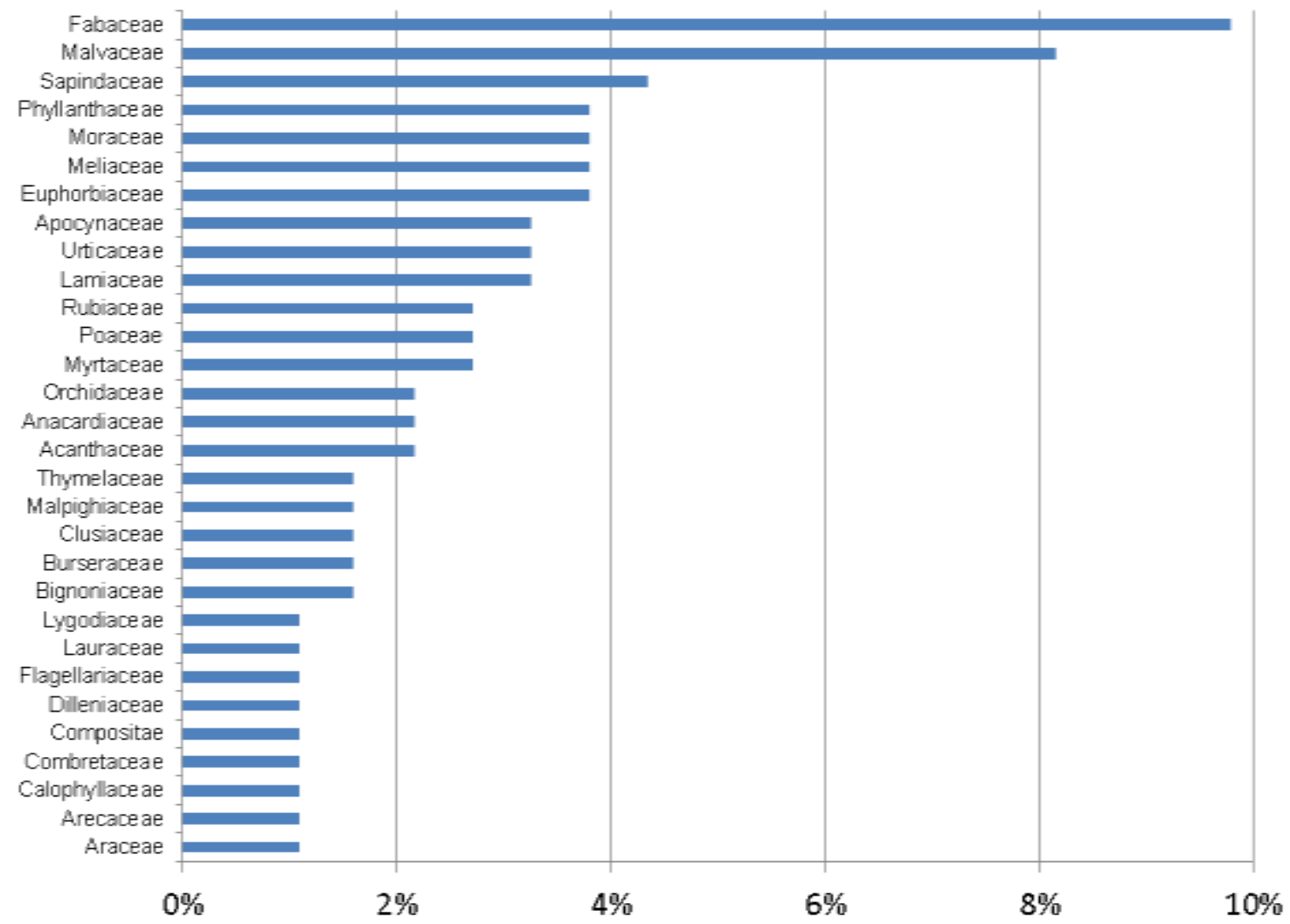

Figure 2. Plant composition (the 30 most dominant families) of study area in Sikka Forest

A total of 18 species of Fabaceae Family were found in all stages (trees, sapling, and ground cover) inside the Egon Ilimedo Protected Forest. There were also 15 species of Malvaceae and 8 species of Sapindaceae found in all stages. In total, there were 184 species from 61 families inventoried from the Egon Ilimedo Protected Forest at an altitude of 0-700 m asl. The total species in this result was higher than previous research reported by Kali et al., (2015) that stated that in the four spring area in Belu, Timor Island, East Nusa Tenggara (Lahurus, Wetihu, Wewai, and Mauhalek) there were 71 species categorized into 30 Family. Previous research conducted by Ariyanti \& Mudiana (2011) also in the Waigette sub-district, Sikka District, collecting 112 species plant samples that were categorized into 85 Families.

Based on the cruising method results, it was known that there were different types of vegetation at certain altitudes and stages (trees, saplings, and ground cover). The observed area was divided into three zoning altitudes.

\section{Vegetation at $0-200 \mathrm{~m}$ asl}

The study area of $0-200 \mathrm{~m}$ asl is presented in Figure 3. The observation noted that the trees frequently found were Terminalia catappa, Pongamia pinnata, Pometia pinnata, Cocos nucifera, Borassus flabellifer, Schleichera oleosa and Tamarindus indica. The sapling frequently found were Pometia pinnata, Pongamia pinnata, Pandanus tectorius, Caesalpinia bonduc, and Morinda citrifolia. While ground cover species frequently found were Ipomoea pes-caprae, Calotropis gigantea, Ageratina havanensis, and Typha angustifolia. 


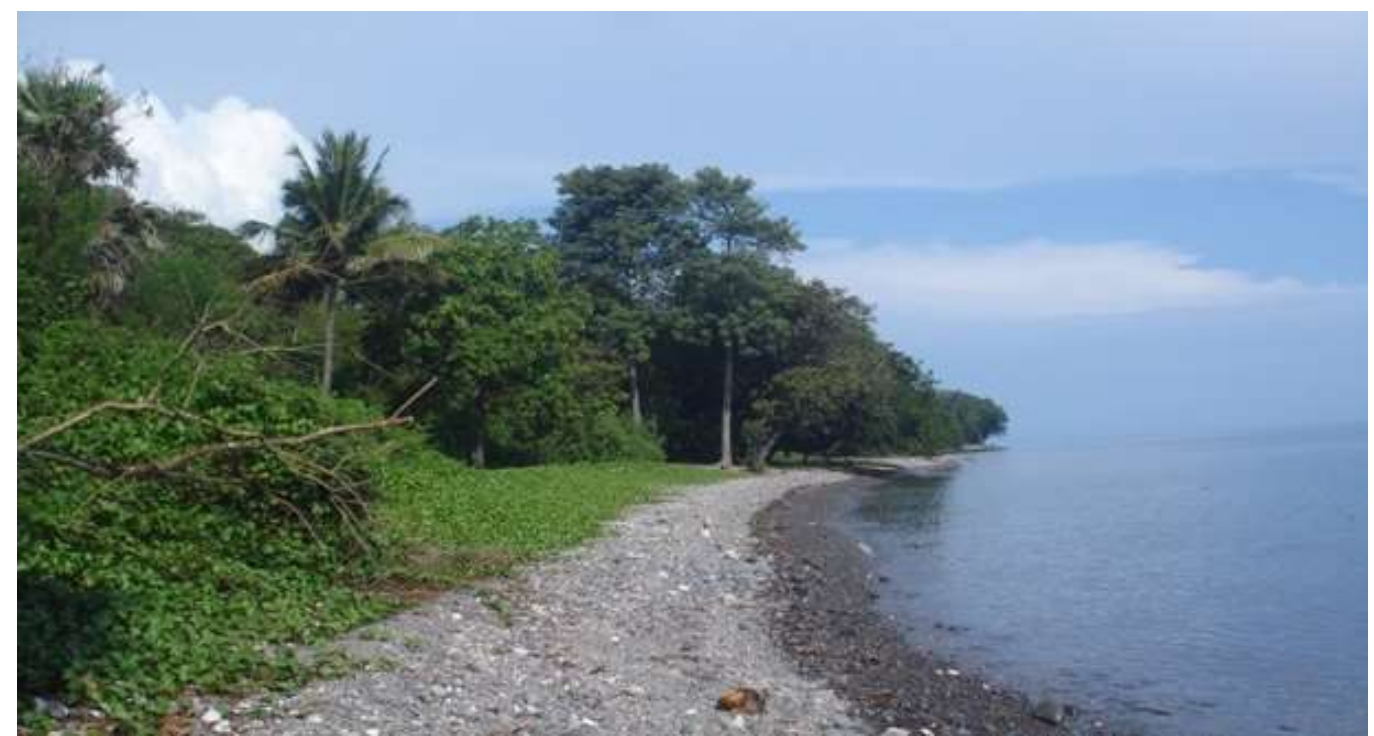

Figure 3. Area study of 0-200 $\mathrm{m}$ asl

IVI or Important Value Index is a parameter that might show the role of a species in the ecosystem they live (Sundarapandian \& Swamy, 2000). Coconut has the highest IVI (37.03) (Figure 4), followed by Terminalia catappa (IVI 34.6) and Pommetia pinnata
(IVI 25.8). Coconut was native to tropical area, originated from Maluku as well. In the saplings and ground covers stages, Pandanus tectorius and Ipomoea pes-caprae are two species with highest IVI, with values are 32.13 and 85.33 respectively.

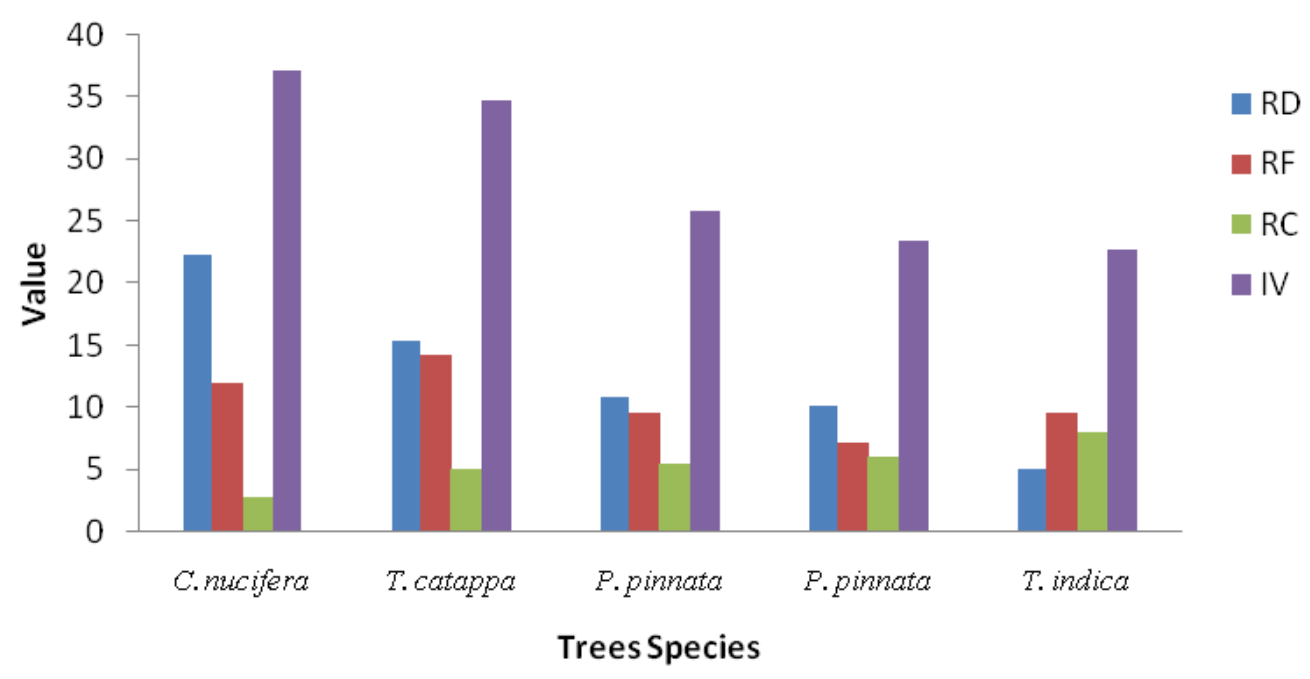

Figure 4. Five tree species with the highest Important Value Index (IVI), Relative Density (RD), Relative Frequency (RF), and Relative Coverage (RC)

The diversity index for trees, saplings, and ground cover were categorized as low since the values were only $2.42,2.59$, and 1.62 respectively. This condition occurred because of the dominancy of Cocos nucifera for tree, Pandanus tectorius for sapling, and Ipomoea pes-caprae for ground cover (Figure 5). However, this condition is better than the diversity index of mangrove areas in Kupang Bay Sea Nature Park, which was only 0.01 to 0.71 (Bessie et al., 2013), while in the Belo and Labat, the riparian tree diversity index only reached 1.85 and 1.45 respectively (Semiun $\&$ Lengur, 2018). The low diversity index value in the mangrove area generally is due to the dominance of certain species. In addition, the mangroves area which is used as a recreation area, such as in the Kupang Bay Sea Nature Park, tends to have worse vegetation conditions than the natural mangroves area. 
Abban Putri Fiqa et al. / Biosaintifika 12 (2) (2020): 192-202

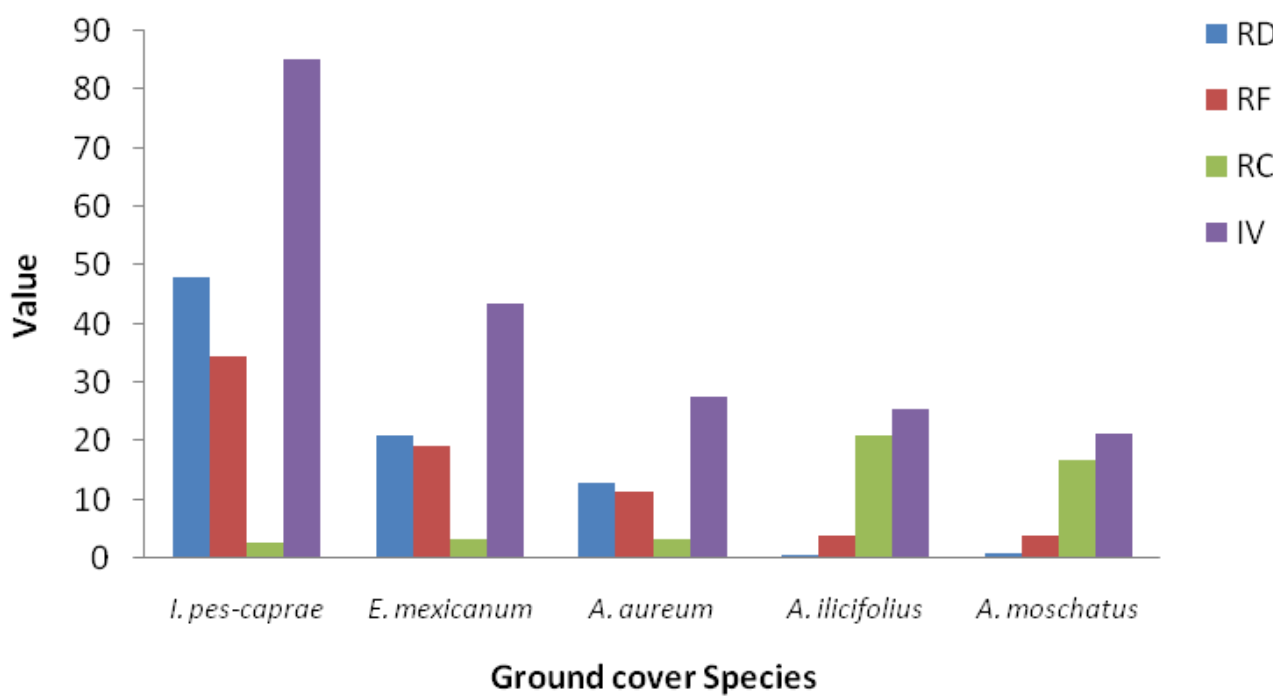

Figure 5. Five ground cover species with the highest Important Value Index (IVI), Relative Density (RD), Relative Frequency (RF), and Relative Coverage (RC)

\section{Vegetation at 200-500 $\mathrm{m}$ asl}

The study area of $200-500 \mathrm{~m}$ asl is presented in Figure 6. Schleichera oleosa, Homalium sp., Tamarindus indica, Ziziphus jujuba, Ficus spp., and Albizia chinensis were frequently found at lowland forest at the altitude $200-500 \mathrm{~m}$ asl. Orchids found in this altitude were epiphytic and terrestrial orchid, such as Dendrobium spp., Vanda sp., Thrixspermum sp., Habenaria spp. and Nervilia punctata.

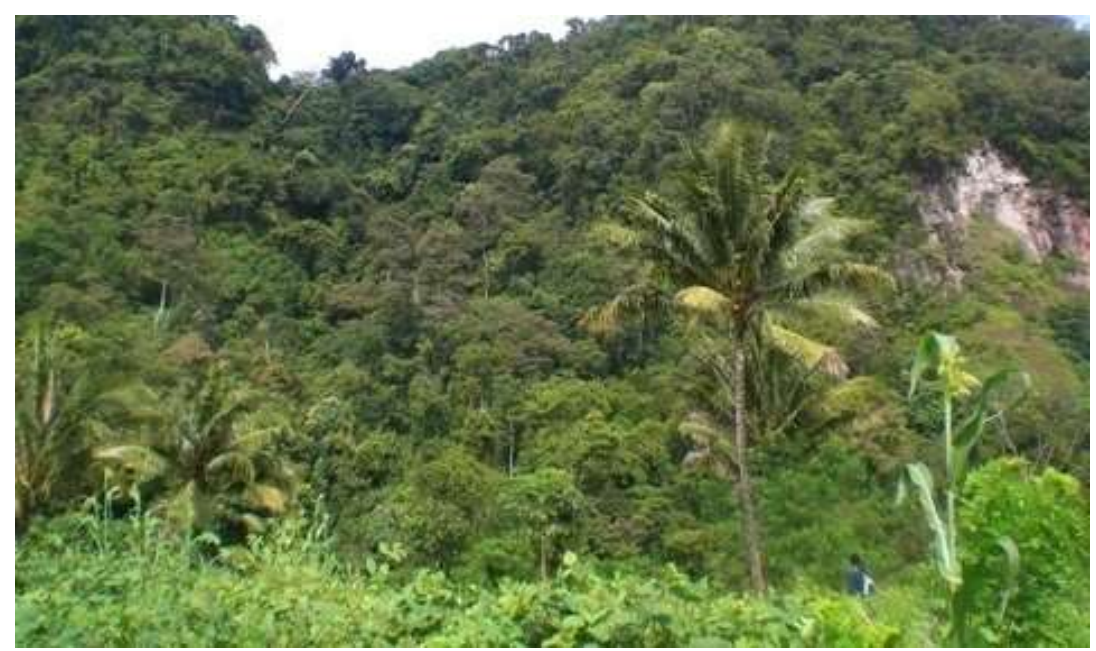

Figure 6. Area study of 200-500 m asl

At the 200-500 m asl, the Important Value Index of Schleichera oleosa (34.37) became the highest among all species (Figure 7). The second and third place was belong to Artocarpus elasticus and Ficus sp.2, which is included in Moraceae Family. Schlei- chera oleosa was also found to be dominant species in the dry forest area Rote Ndao Regency, East Nusa Tenggara, with higher IVI by 116.18 (Almulqu \& Boonyanuphap, 2018). 


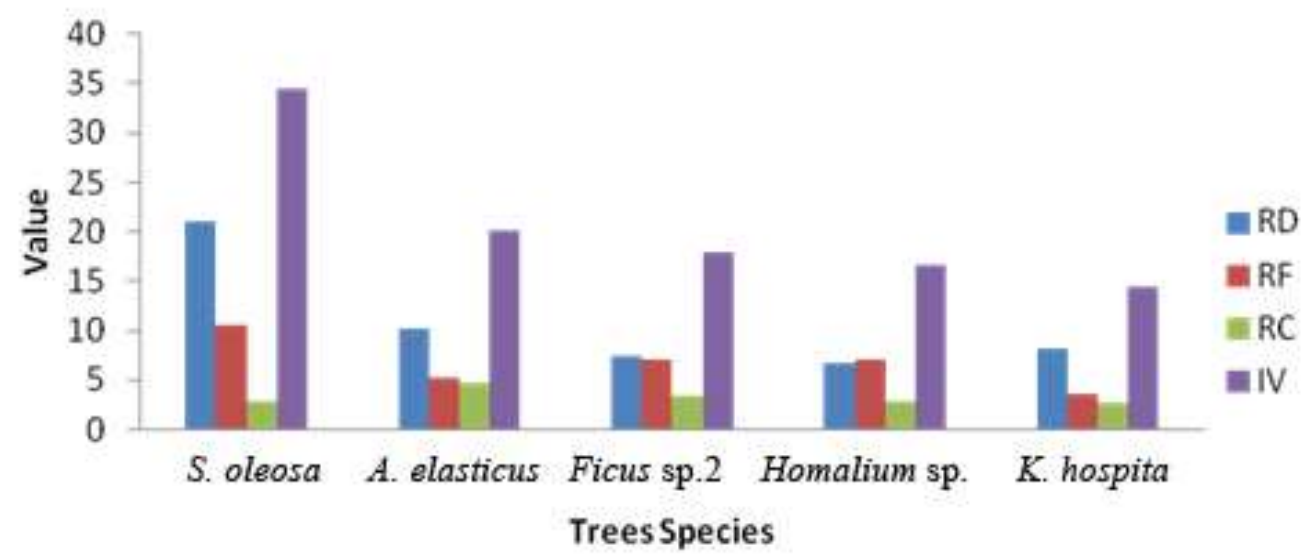

Figure 7. Five tree species with the highest Important Value Index (IVI), Relative Density (RD), Relative Frequency (RF) and Relative Coverage (RC)

Sterculia sp. from Sterculiaceae with IVI of 21.10, addition, the highest IVI for ground cover is shown became the most important species for the sapling. In by Oplismenus sp. (35.64), as seen in Figure 8.

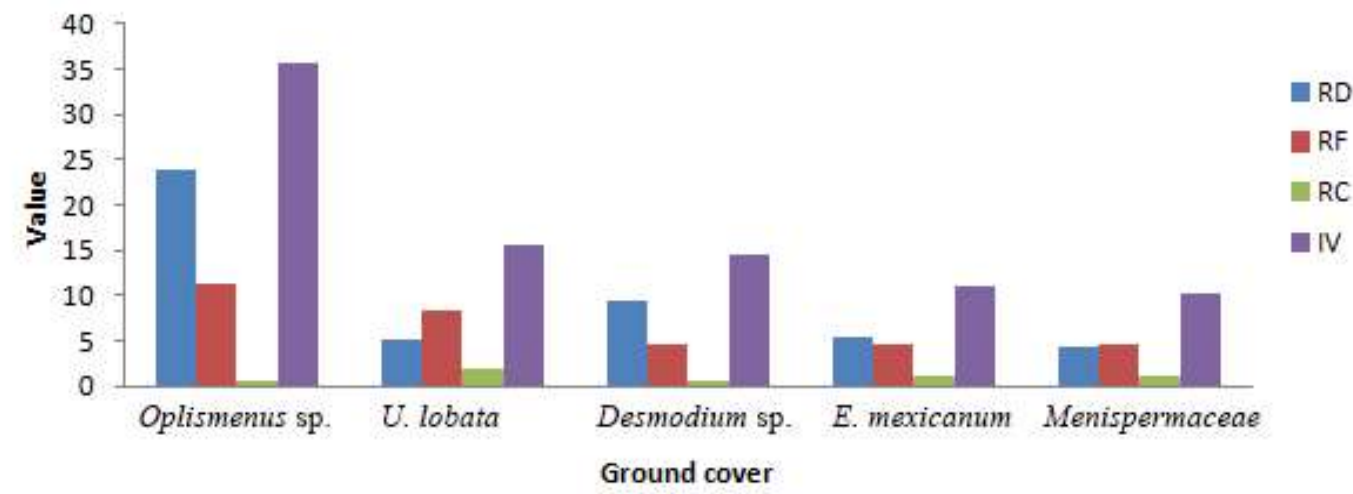

Figure 8. Five ground cover species with the highest Important Value Index (IV), Relative Density (RD), Relative Frequency (RF) and Relative Coverage (RC)

As described in Monk et al. (1997), the ground cover of lowland forests in East Nusa Tenggara was dominated by Oplismenus. However, the diversity index for ground cover was categorized as high (3.23) and higher than the diversity index of groundcover in the South central Timor Regency located in Timor Island which was only 1.19 (Lio \& Dewi, 2018). The diversity index value of trees and sapling in this altitude at East Nusa Tenggara lowland forest were 2.94 and 3.38 respectively and categorized as moderate.

\section{Vegetation at 500-700 $\mathrm{m}$ asl}

An endemic tree from East Nusa Tenggara called aтрири (Eucalyptus urophylla) was found in this zone. The dominant ground cover in this area is Imperata cylindrica. Some exotic plant species of terrestrial and epiphytic orchid such as Crepidium heeded, Goodyera rubicunda, Corybas insulifloris, Dendrobium spp., Acriopsis sp., Nervilia spp., and Thesis sp. were also found in this area. The study area of 500$700 \mathrm{~m}$ asl is presented in Figure 9. 


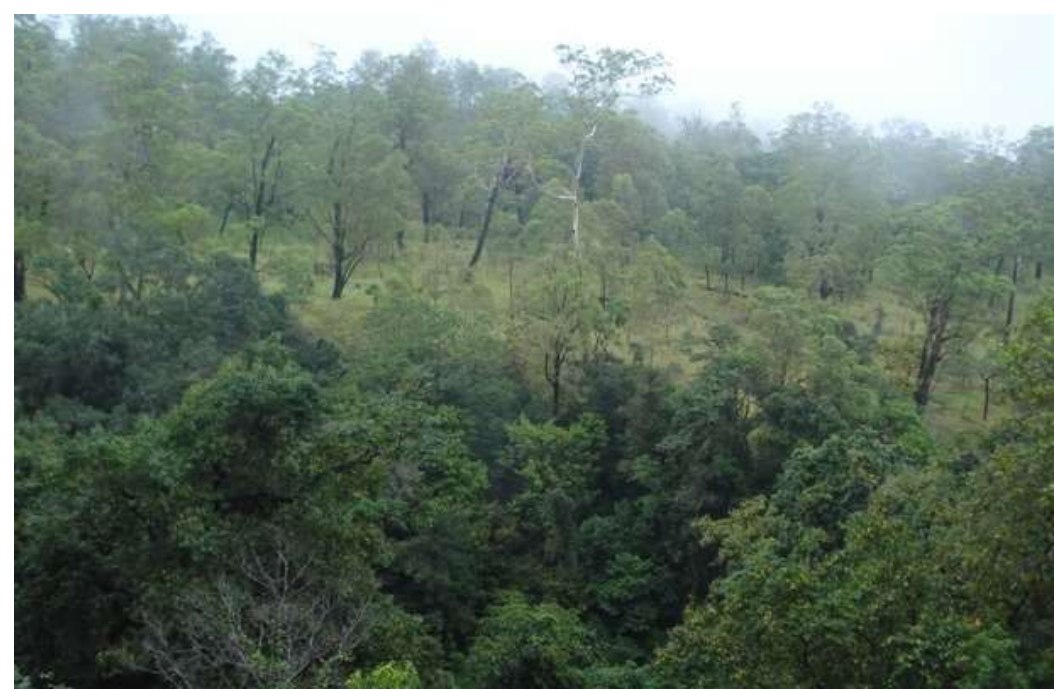

Figure 9. Area study of 500-700 m asl

Eucalyptus urophylla was found to be the most important tree species based on their abundance, frequency and coverage area. It is shown from its IVI compared with the other trees species (Figure 10).
This result is in line with the previous study which showed that E. urophylla dominated the vegetation of Nature Reserve of Mount Mutis, East Nusa Tenggara province (Almulqu et al., 2017).

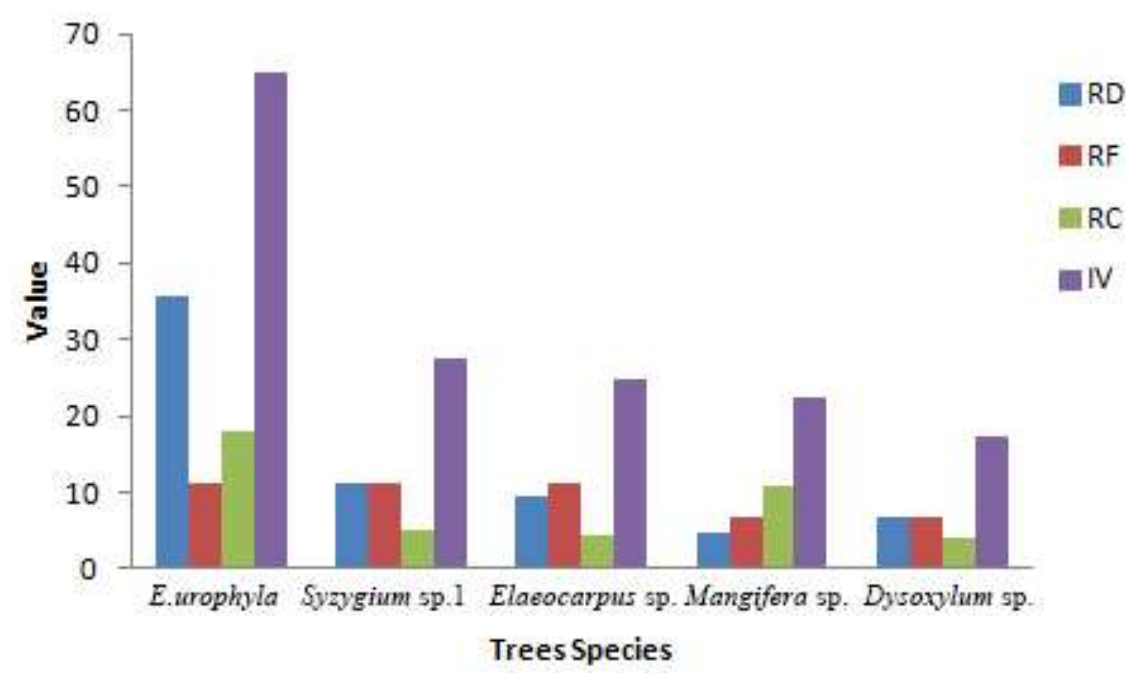

Figure 10. Five tree species with the highest Important Value Index (IVI), Relative Density (RD), Relative Frequency (RF) and Relative Coverage (RC)

Eucalyptus trees found in Nusa Tenggara consisted of three endemic species (Eucalyptus urophylla, Eucalyptus urophilia, and Eucalyptus wetarensis). E. urophylla form a unique habitat type, the mountainous season forests with an open canopy. It was found in Flores, Adonara, Lembata, Lomblen, Alor and West Timor, with region - Mt. Egon Illimudu, Lewotobi, Mutis, and Timau (BKLH, 2013). Unfor- tunately, the abundant of young trees of E. urophylla were not found as much as the tree. Sapling stage was dominated by Syzygium sp2, Garcinia sp1, and Garcinia sp2 (Figure 11). It could be a sign for local government to start conserving E. urophylla, since it was included in IUCN Red List category as Endangered species. 


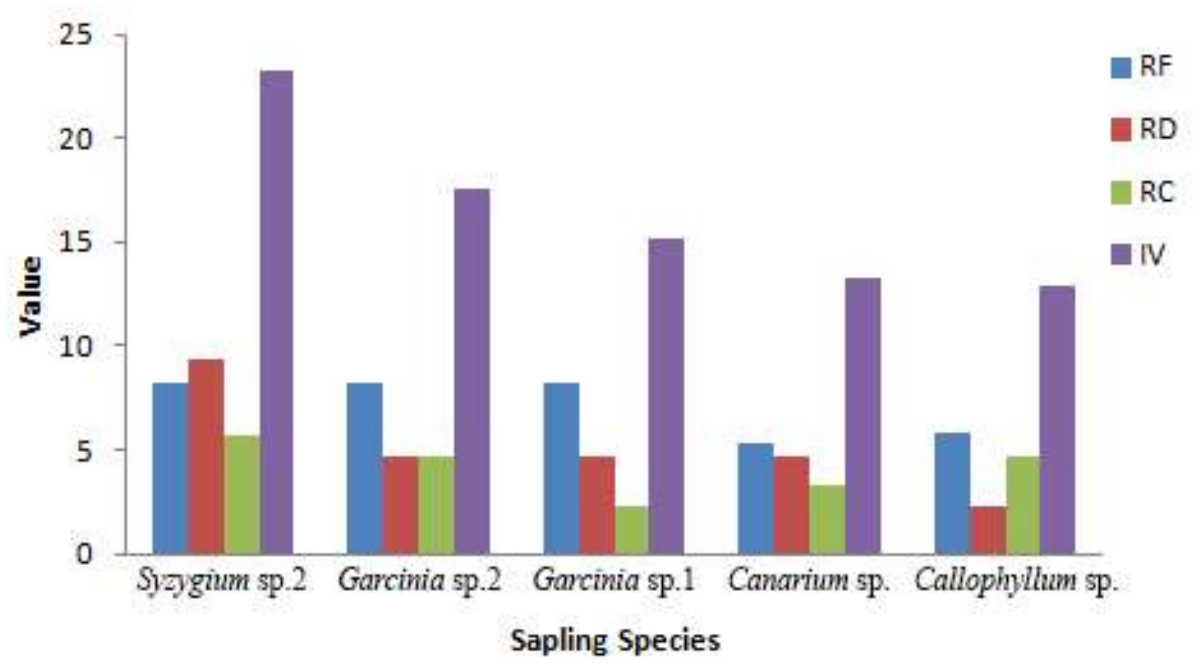

Figure 11. Five sapling species with higest Important Value Index (IVI), Relative Density (RD), Relative Frequency (RF) and Relative Coverage (RC)

Due to the long dry season and forest burning, the composition of ground cover in the altitude of 500$700 \mathrm{~m}$ asl has dominated by Imperata cylindrica and Ageratina havanensis as an indication of degraded ecosystem. However, it turns out that indigenous peo- ple utilize I. cylindrical as traditional medicinal ingredients and animal feed (Iswandono et al., 2015). Oplismenus sp., as native plants in lowland forest, only occupied the fifth position for their IVI (Figure 12).

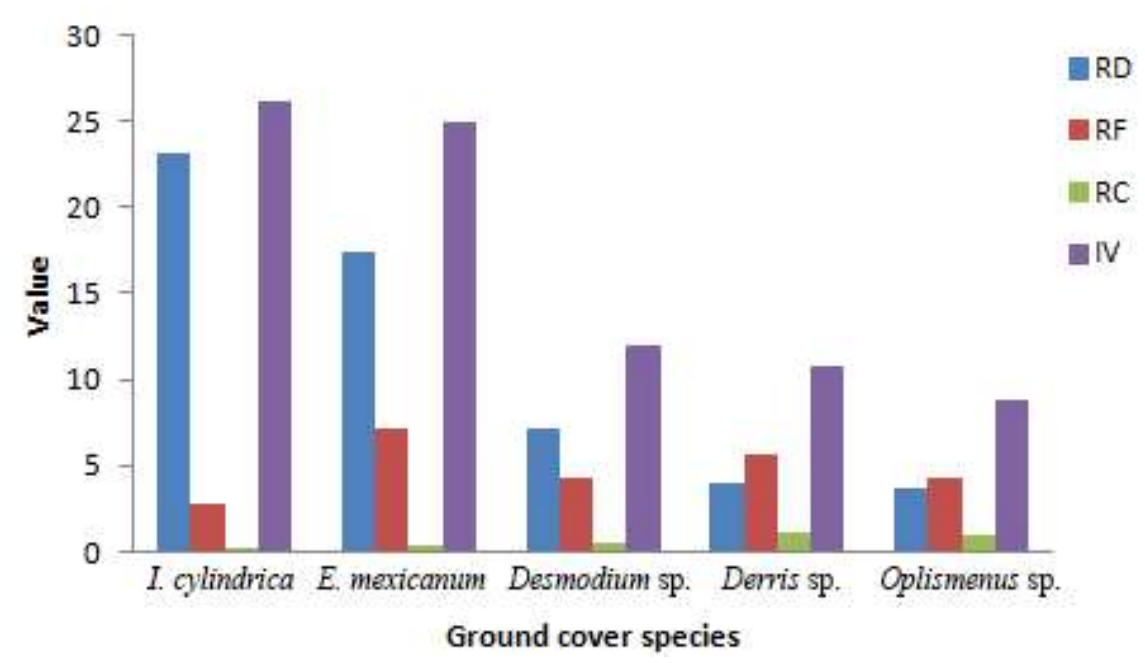

Figure 12. Five ground cover species with the highest Important Value Index (IVI), Relative Density (RD), Relative Frequency (RF) and Relative Coverage (RC)

The diversity index for trees, sapling, and ground cover was $2.30,3.28$, and 2.91 , respectively. In this altitude, the diversity index of trees was very low because of the dominance of E. urophylla. Tree diversity index in the Egon Ilimedo protection forest at 500-700 $\mathrm{m}$ asl was higher than the one reported in Manokwari District with diversity index of 1.65, 1.78, and 1.55 for trees, sapling and groundcover respectively (Mahmud et al., 2019).

\section{Similarity of Three Areas Observed}

The Jaccard similarity index is presented in Table 1. This value indicates that there is a difference in vegetation structure between the three areas observed. Low similarity index also shows that there are species of habitat identifiers, i.e., species that are only found in certain habitats. More over, the different vegetation types would also cause a different fauna living in the area (Rahayuningsih et al., 2010). Only seven species were found both in $0-200 \mathrm{~m}$ asl and $200-500 \mathrm{~m}$ asl, four species in both $0-200 \mathrm{~m}$ asl and $500-700 \mathrm{~m}$ asl, and 13 species in both $200-500 \mathrm{~m}$ asl and $500-700 \mathrm{~m}$ asl. 
Abban Putri Fiqa et al. / Biosaintifika 12 (2) (2020): 192-202

Table 1. Jaccard Similarity Index in the observed area

\begin{tabular}{llll}
\hline & $0-200 \mathrm{~m}$ asl & $200-500 \mathrm{~m}$ asl & $500-700 \mathrm{~m}$ asl \\
\hline $0-200 \mathrm{~m}$ asl & & $5.69 \%$ & $5.88 \%$ \\
$200-500 \mathrm{~m}$ asl & & $12.15 \%$ \\
$500-700 \mathrm{~m}$ asl & & \\
\hline
\end{tabular}

From the environmental factors measured during the field study, it was shown that the temperature and relative humidity in each altitude area observed were significantly different (Table 2). The temperature in the 500-700 m asl forest area was the lowest and keep increasing along with decreasing altitude. Conversely, the higher the altitude, the lower the temperature measured. This is in line with research conducted by Fiqa \& Darmayanti (2018) in the East Java forests. In addition, the temperature is also inversely proportional to the humidity. This significant difference in temperature and humidity can be caused by differences in vegetation density in the three observed areas. The value of Relative Density of the trees in the area 500-
$700 \mathrm{~m}$ asl is higher than the other two areas. However, the soil $\mathrm{pH}$ in the area observed was not significantly different. Soil $\mathrm{pH}$ values in the three areas are not significantly different because all three areas are still in the Egon Ilimedo volcanic forest area that is known as a fertile area. Plant distribution always related closely with the environmental factor. Some species are able to live in the shade, while others are not. The density, coverage, and frequency of the species is affected by the ability of the species to adapt the environmental factors such as temperature, relative humidity, soil $\mathrm{pH}$ and many others (Yulistyarini et al., 2020).

Table 2. The microclimate of the study area

\begin{tabular}{llll}
\hline Study area $(\mathrm{m}$ asl $)$ & soil $\mathrm{pH}$ & Temperature $\left({ }^{\circ} \mathrm{C}\right)$ & Relative humidity $(\%)$ \\
\hline $0-200$ & $6.52 \pm 0.34^{\mathrm{ab}}$ & $36 \pm 0^{\mathrm{c}}$ & $69.67 \pm 4.41^{\mathrm{a}}$ \\
$200-500$ & $6.82 \pm 0.18^{\mathrm{b}}$ & $32 \pm 1.26^{\mathrm{b}}$ & $79 \pm 1.67^{\mathrm{b}}$ \\
$500-700$ & $6.28 \pm 0.28^{\mathrm{a}}$ & $27.17 \pm 1.17^{\mathrm{a}}$ & $93.33 \pm 6.28^{\mathrm{c}}$ \\
\hline
\end{tabular}

This vegetation composition difference of the three altitudes showed that the Egon Ilimedo Protected Forest area needs more concern. Land degradation that occurs in one area will have a major effect on biodiversity in the whole area since one species might not be found in the different altitude, even though the difference in the altitude is not too large. Education to the people who live around the forest is essential, considering that they also get a lot benefit from the forest. In addition, it is estimated that there are still many more plant species whose uses are still unknown in this forest area.

\section{Implication for conservation, science, and society}

Natural forests in the Egon Ilimedo region, Flores Island, have unique vegetation characteristics that vary at each altitude. This can be seen from the low level of similarity among three observed areas. Flores Island has a lot of unreaveled potential yet, especially the diversity of plants. Many endemic species are also protected in this area, such as agarwood (Gyrinops verstegii), which is included in the CITES appendix II list, and sandalwood (Santalum album). Unfortunately, scientific publications about vegetation on Flores Island are very limited when compared to their potential and the enormous threats. Some research on vegetation diversity began to be carried out in several re- gions of Flores such as in West Manggarai (Yulistyarini et al, 2020), Manggarai (Fiqa et al., 2020), East Manggarai, Nagekeo, and Ngada (Sutomo et al., 2020). This research will enrich the literature on the diversity of vegetation in the eastern part of Flores Island.

For the sake of conservation, this research was conducted in line with time, along with the increasing number of forest areas encroached for both residential and agricultural settlements. Rare and endemic species related to the location of Flores Island in the biodiversity hotspot need to be recognized immediately to be conserved and protected. Furthermore, forests as natural habitat for wildlife also carry important missions for the balance of life. Conserve forests means conserving all organisms using forests as their habitat.

In terms of science, this research will be very meaningful as a basis for other research related to species with bioprospecting potential. Flores Island is known as a living habitat for various types of agarwood that are in high demand for trade. Agarwoods are known for their potential use as medicinal ingredients and parfume raw material. Introducing the plants species with economic, health or food potential will attract the interest of the community to conserve the plants, by cultivating them. Conserving forest areas with diverse vegetation is also expected to 
maintain natural stability and to prevent people from natural disasters such as drought and forest fires in the dry season or flooding in the rainy season.

\section{CONCLUSION}

Vegetation composition in three different altitudes in Sikka forest area is relatively different. It was indicated by the different plant combinations and dominancy in all stages (trees, saplings, and ground covers). The difference among them could also be seen from the difference of their environmental factors. Ampupu (Eucalyptus urophylla), an endemic tree from East Nusa Tenggara is the dominant tree at the 500-700 $\mathrm{m}$ asl of forest area. Three of those areas have low diversity index (less than 4.00). Local government should pay more attention to the Sikka forest area because there are many endemic and endangered species such as E. urophylla and many species of orchid in Sikka forest.

\section{REFERENCES}

Almulqu, A.A., Arpornpong, N., \& Boonyanuphap, J. (2017). The Study of Tree Species Diversity in Dry Forest of East Nusa Tenggara, Indonesia. Alexandria Science Exchange Journal: An International Quarterly Journal of Science Agricultural Environments, 38 (October-December), 752-760.

Almulqu, A.A., \& Boonyanuphap, J. (2018). Aboveground biomass in tropical dry forest at Rote Ndao Regency, East Nusa Tenggara Province, Indonesia. Naresuan University Journal: Science and Technology, 26(1), 49-62.

Amalo, P. (2019). Kebakaran hutan lindung Egon Ilimedo berhasil dipadamkan. Retrieved on February 25,2020 , from https://mediaindonesia.com/ read/detail/262713-kebakaran-hutan-lindungegon-ili-medo- berhasil-dipadamkan.

Ariyanti, E.E. (2010). Pemanfaatan Berbagai Jenis Tumbuhan Sebagai Bahan Pangan Di Dusun Di Dusun Blidit, Desa Egon, Kecamatan Waigete, Kabupaten Sikka, Provinsi NTT. Berkala Penelitian Hayati Edisi Khusus, 4A, 55-58.

Ariyanti, E.E., \& Mudiana, D. (2011). Eksplorasi Flora Di Dusun Blidit, Desa Egon, Kecamatan Waigete, Kabupaten Sikka Propinsi Nusa Tenggara Timur. Berk. Penel. Hayati Edisi Khusus, 5A, 9-14.

Bacon, C.D., Michonneau, F., Henderson, A.J., Mckenna, M.J., Milroy, A.M., \& Simmons, M.P. (2013). Geographic And Taxonomic Disparities In Species Diversity: Dispersal And Diversification Rates Across Wallace's Line. Evolution, 67(7), 2058-2071.

BKLH. (2013). Keystone Species Nusa Tenggara. Balai kliring Keanekaragaman Hayati Nasional
KLH. Retrieved from http://www.indonesianchm. co.cc/index.php?option $=$ comcontent $\&$ view $=$ article \&id=170\&Itemid=366\&lang=en .

BPS Nusa Tenggara Timur. (2019). Provinsi Nusa Tenggara Timur dalam Angka 2019. Kupang.

Darmayanti, A.S., \& Wuryanti, S. (2010). Inventarisasi Tumbuhan Berkhasiat Obat Di Wilayah Desa Egon, Kecamatan Waegete, Kabupaten Sikka Nusa Tenggara Timur. Berkala Penelitian Hayati, 4, 5-11.

Fiqa, A.P. \& Darmayanti, A.S. (2018). Floristic and Soil Characteristic at The RPH Sentul-Probolinggo Protected Low Land Forest, East Java. Journal of Tropical Biodiversity and Biotechnology, 3, 18-25.

Fiqa, A.P., Budiharta, S., Siahaan, F.A., \& Rindyastuti, R. (2020). Population structure of Gyrinops versteegii within floristic community in Nggalak Protection Forest, Flores Island, Indonesia. Biodiversitas, 21(4), 1561-1568.

Hirschberger, P. (2017). Forests Ablaze : Causes and effects of global forest fires. Berlin.

Indonesian Ministry of Forestry. (1999). SK Menteri Kehutanan Nomor 423/Kpts-II/1999. Jakarta: Kementerian Kehutanan.

Iswandono, E., Muhammad Zuhud, E.A., Hikmat, A., \& Kosmaryandi, N. (2015). The Ethnobotany Knowledge of Manggarai Tribe and the Implication Utilization of Forest Plants in The Mountains of Ruteng. Jurnal Ilmu Pertanian Indonesia, 20(3), 171-181.

Juárez-Orozco, S.M., Siebe, C., \& Fernández y Fernández, D. (2017). Causes and Effects of Forest Fires in Tropical Rainforests: A Bibliometric Approach. Tropical Conservation Science, 10(1), 114.

Kali, F.B., Kusuma, Z., \& Leksono, A.S. (2015). Diversity of vegetation around the springs to support water resource conservation in belu, East Nusa Tenggara, Indonesia. Jurnal of Biodiversity and Environmental Sciences, 6(4), 100-114.

Lanur, H., \& Mago, O.Y.T. (2018). Eksplorasi Tumbuhan Obat Tradisional Desa Blata Tatin Kecamatan Kangae Kabupaten Sikka. Jurnal Saintek Lahan Kering, 1(2), 24-25.

Lio, F.X.S., \& Dewi, M.P.S. (2018). Diversity of floor vegetation in various levels in South Central Timor, East Nusa Tenggara, Indonesia. Biodiversity International Journal, 2(5), 476-482.

Lipsett-Moore, G.J., Wolff, N.H., \& Game, E.T. (2018). Emissions mitigation opportunities for savanna countries from early dry season fire management. Nature Communications, 9(2247), 1-8.

Magurran, A.E. (1988). Ecological Diversity and Its Measurement. New Jersey: Pricenton University Press. 
Mahmud, M., Kusumandari, A., Sudarmadji, S., \& Supriyatno, N. (2019). The Species Diversity and Structure of The Limited Production Forest in Arui Watershed of Manokwari District of West Papua, Indonesia. Biosaintifika, 11(2), 279-288.

Ministry of Environmental and Forestry of Indonesia. (2014). The Fifth National Report of Indonesia to the Convention on Biological Diversity. Jakarta Timur. Retrieved from https://www.cbd.int/doc/world/id/id-nr-05-en.pdf

Monk, K.A., de Freter, V., \& Reksodiharjo, G. (1997). The Ecology of Nusa Tenggara and Maluku (The Ecology of Indonesia Series Volume V). Singapore: Periplus Edition.

Niemiec, R.M., Asner, G.P., Brodrick, P.G., Gaertner, J.A., \& Ardoin, N.M. (2018). Scale-dependence of environmental and socioeconomic drivers of albizia invasion in Hawaii. Landscape and Urban Planning, 169, 70-80.

Rahayuningsih, M., Purnomo, F.A., \& Priyono, B. (2010). Keanekaragaman Burung di Desa Karangasem Kecamatan Wirosari Kabupaten Grobogan Jawa Tengah. Biosaintifika, 2(2), 82-89.
Semiun, C.G., \& Lengur, E.R.A. (2018). The Profile of Riparian Tree Grown in the Area of Water Springs in Kupang, Nusa Tenggara Timur Province Indonesia. International Journal of Sciences : Basic and Applied Research, 42(5), 75-83.

Sundarapandian, S.M., \& Swamy, P.S. (2000). Forest ecosystem structure and composition along an altitudinal gradient in the Western Ghats, South India. Journal of Tropical Forest Science, 12(1), 104123.

Sutomo, Darma, I.D.P., \& Iryadi, R. (2020). Short communication: The dissimilarity in plant species composition of savanna ecosystem along the elevation gradient on Flores Island, East Nusa Tenggara, Indonesia. Biodiversitas, 21(2), 492496.

Yulistyarini, T., Fiqa, A.P., Budiharta, S., \& Rindyastuti, R. (2020). Distribution of Gyrinops versteegii in varying vegetation structures, soil properties, and microclimates in western part of Flores Island, Indonesia. Biodiversitas, 21(5), 1800-1808. 